\title{
96 事務室内の視的快適性に関する模擬太陽光を用いた実験
}

$$
\text { その } 1 \text { モデリングの検討 }
$$

南幸伸

早稲田大学大学院早稲田大学理工学研究所

宿谷昌則

武葴工業大学工学部
木村建一

早稲田大学理工学部

1.はじめに

立体感、質感を考虑に入れた視対象の見え方、即ちモテリングは、室内の光環境の块適 性に影锌を及ほすと考えられる。適正なモテリングは一般事務室、会議室など部屋の用途 によっても異なると考えられる。モテリング評価の一方法としてCuttleは、光の方向性を 表すべクトル高度、指向性の光と拡散性の光による照度比を表すべクトル・スカラ一比と

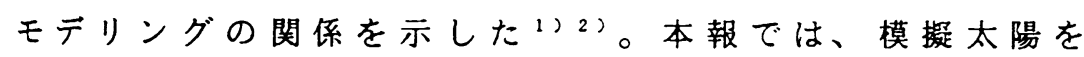
用いた実験室内で被験者実験を行い、Cuttleの実験結果 と照らし合わせて検討した結果について報告する。

2 . 実験方法

1992年 6月、新菱冷熱（株）㞬間シミュレーションルー离 ム(つくば市)において実験を行った。図1にその平面、 及び天井伏、図2 に断面を示す。図2 に示すように窓の 外には昼光を模擬した人工光源が設置してあり、室内は 一般事務室を模擬して机等が配置されている

表1に示す実験条件の1つにおいて、被験者 12 名を図 1 の各位置に着席させ簡単な作業を 25 分間行わせた後、 光環境に関する一連の質問に回答させ、その後退出させ る。1 日当たり $9 \sim 10$ 条件で 6 日間実験を行った。被験 者の総数は67名（男33、女34）ですへて日本人大学生で ある。モテリングに関する申告には図3に示すスケール を用い、被験者はスケール上に綎線を引いて申告した。 受け入れられない侧、すなわちスケールの左半分に線を 引いた人の全被験者に対する割合を不満率とした。図 1 に示したように空面に垂直に $\mathrm{A} \sim \mathrm{D}$ 列、窓面に平行に $\mathrm{I}$ 〜 V列を設定し、それぞれの位置でスカラ一照度、べク トル照度等を算出するために各面の照度を测定した。べ クトル照度の水平成分の方向はすへて悹面と垂直とした。 3 . 結果亡考察

3-1 点灯状態による物理量の変化

目 4、5にベクトル高度とベクトル・スカラ一比をI 〜 Vの列ごとに平均した值を示す。図4 は空面がブライ ンドの場合、図 5 はブラインドと反射ルーバーを組み合 わせた場合で太陽高度 60 度について示す。図中の実線は Cuttleの示した不満率である。図5 中には参考のため日 射無し全点灯の場合も示すが、ベクトル高度が高く、不 满率が $10 \%$ 以下の範囲にある。ブラインド、反射ルーバ 一とも人工照明を消灯した場合には、いずれの位置でも ベクトル高度が小く（横からの光が強く）べクトル・ スカラー比が大きくなり、予測されるモテリングもかな

Experimental study on visual comfort in office space with simulated daylight Part 1. Evaluation of modelling

Yukinobu Minami, Toshie Iwata, Masanori Shukuya and Ken-ichi Kimura
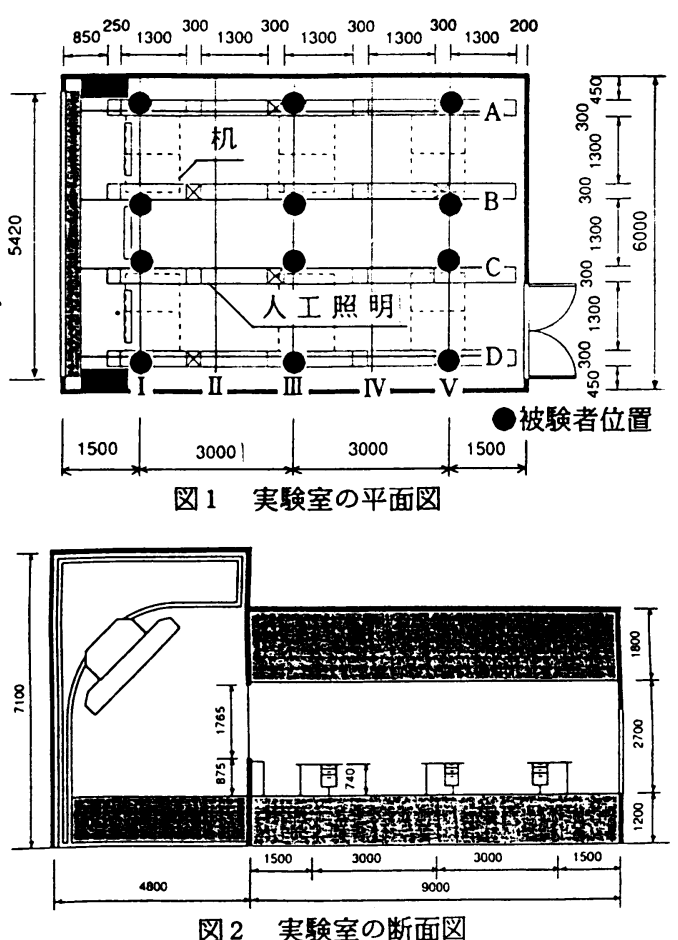

1)向かい合っている人の就が光のあたり方によって不自 然に感じますか。

$\square$ はい ロいいえ

2) 1) ではいと答えた人は、向かい合っている人の顔の 見え方はオフィスとして受け入れられるむのですか。 下のスケールに綎縜を引いて答えて下さい。

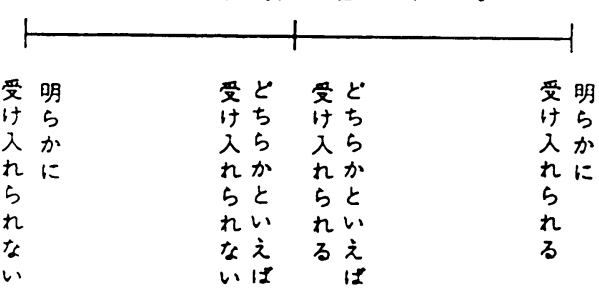

図 3 申告用紙

表 1 実験条件

\begin{tabular}{|c|c|}
\hline$\overline{\text { 項目 }}$ & 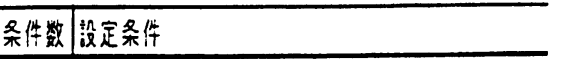 \\
\hline 太量高度 & $245 \sqrt{1}, 60$ 度 \\
\hline 密システム & 3フラインド，フラインド+反射ルーバー方ラス \\
\hline \multirow[t]{3}{*}{ 点奵犾熊 } & 3 全点的 \\
\hline & 圲上面照度7501x一定制御(3列消行，4列消们) \\
\hline & 全消历 \\
\hline
\end{tabular}


りどぎつい域に入っている。ブラインドの場合に机上面 $7501 \times$ を保つため奥から 2 列点灯（ 3 列消灯）すると、図 中矢印で示されるように $\mathrm{V} 、 \mathrm{~V}$ 列ではべクトル高度が大 きくなり、 III IV 列ではべクトル・スカラ一比が小さく なって予測不满率が下がるブラインド+反射ルーバー の場合奥から 1 列点灯すると、 IV 、 V 列で予測不満率の 変化が大きかった。

1 列を点灯するとその直下の席ではべクトル高度が大 きく変わる。また隣の列の席も、ベクトル・スカラ一比 が下がる。これは、ベクトル照度が下がり、スカラ一照 度ががるためである。これらの傾向は、太陽高度が 45 度の場合も同様であった。

照明を全部点灯すれば、ブラインドの場合もブライン ド十反射ルーバーの場合もほとんどの席での予測不满率 は $10 \%$ 末满となる。しかし、部分的に数列を点灯しただ けではその直下と隣の席での不満率しか軽減されないと 予测された。

\section{3-2 モテリング・インテックスと申告値の比較}

図6にCuttleらの実験による予测不满率 ( P P D ) と 本実験の申告による不満率（P D ）の関係を示す。申告 による不満率が $20 \%$ を越えた場合について四中にその条 件を示した。申告が予測不満率を極端に上回る場合は少 ないが、逆に予測値では不满率が高く、実際の申告では 低い不満率を示す場合が多い。この理由の一つとして、 Cuttleの実験では対象室が明らかではないが、本実験は 事務室を対象とした不満率を求めたことが考えられる。 さらに申告が予測より著しく低くなるのは、ブラインド、な ブラインド+ルーバーの場合の葖際の席で多かった。ブ ラインド $60^{\circ}$ の例を図 7 に示す。Cuttleらの研究結果で はいずれの点灯状態でも空に近い席で不満率が高く室奥 にいく程低くなるか、実際には全体的に空に近い席では あまり不満に感していない。

4. 結 論

人工照明を部分点灯すると、その下の列、および隣の 列の範囲内で、モテリングのどぎつさは軽減されると予 測された。しかし、ブラインド、ルーバーのある空の近 くでは予測不满率が高いにもかかわらず、実際の不满率 は低くなり、モテリングの問題だけを考えれば悹際の照 明を点灯する必要はないといえる。

【謝辞】本実験を行うにあたって、新菱冷熱（株）の鈴 木说子氏はじめ関係諸氏、早稲田大学大学院 ・㚼尾严希 君、早稲田大学・宝田裕美子君、鈴木亮一君のこ協力を いただいた。記して謝意を表する。

【参考文献】1)野口:照明のモテリング効果に関する調查 研究、照明学会誌 Vol.65 N0.9 1981 P. 18-23 2 2)Cuttl e. C:Lighting patterns and the flow of light, Light.

Res. Technol. 3 (1971) P. 171

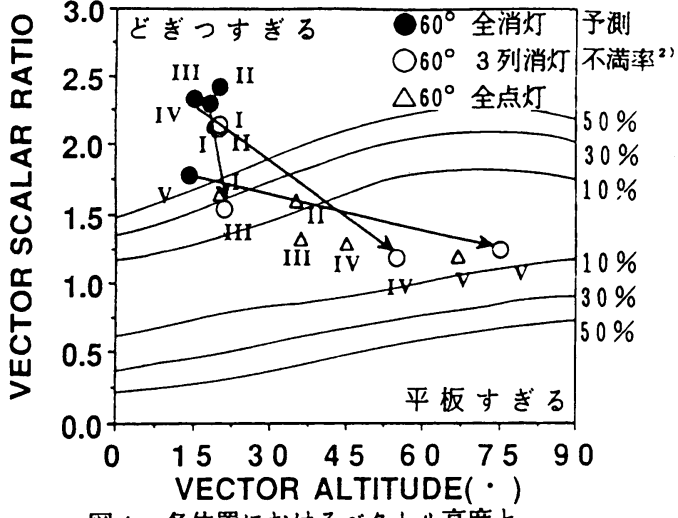

図 4 各位置におけるべクトル高度と

ベクトル・スカラー比（ブラインド）

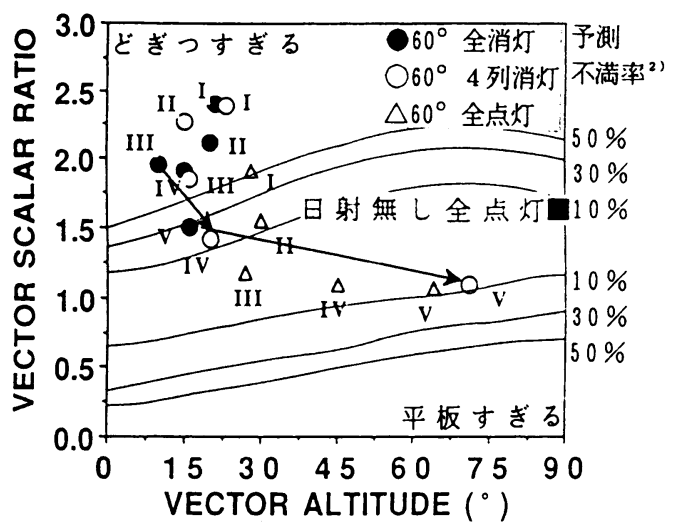

図 5 各位置におけるべクトル高度とべクトル。 スカラー比（ブラインド+反射ルーバー）

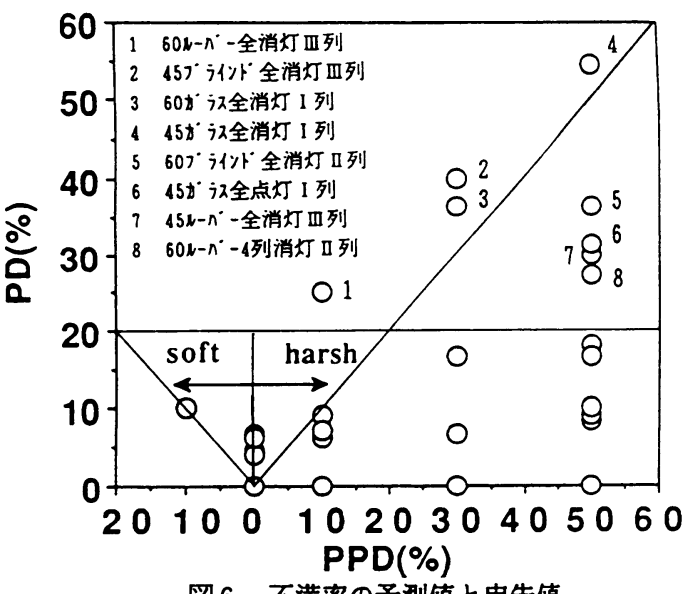

図 6 不満率の予剧值と申告值

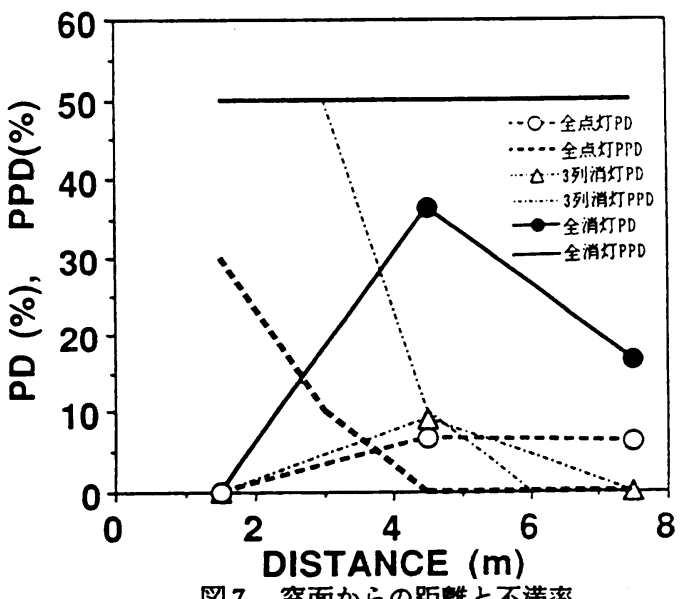

図 7 空面からの距離之不満率

(60フラインド) 